\title{
Detection of Serum Anti-ganglioside Antibodies by Latex Agglutination Assay in Guillain-Barré Syndrome: Comparison with ELISA
}

\author{
Sachiko IRIE, Toyokazu SAITO*, Naomi KanAZAWA, Mieko OgInO, \\ Yutaka OGINO and Fumihiko SAKAI
}

\begin{abstract}
Objective Rapid detection of serum anti-ganglioside antibodies in Guillain-Barré syndrome (GBS) could facilitate early diagnosis and early initiation of treatment, which might shorten the term of illness and reduce sequelae. We examined serum anti-ganglioside antibodies in patients with GBS using the latex agglutination assay developed by Alaedini and Latov (J Immunoassay 21: 377-386, 2000) with some modifications.

Materials and Methods We used 75 sera from GBS patients, which exhibited IgG anti-GM1, GD1b, or GQ1b, or IgM anti-GM2 antibodies on previous enzyme-linked immunosorbent assay (ELISA). Blue latex beads $(2.5 \%$ solution of $0.3 \mu \mathrm{m}$ ) were coated with $1 \mathrm{mg} / \mathrm{ml}$ of GM1, GD1b, GQ1b or GM2. Aliquots $(4 \mu \mathrm{l})$ of serum and the ganglioside-coated particles were mixed and rocked on a glass slide for 30 to 40 seconds. The reaction was observed under a microscope and compared with the antiganglioside antibody titers determined with ELISA.

Results Agglutination was strong in sera of which the IgM or IgG titers of anti-GM1, GD1b, GQ1b or GM2 antibodies were found to be more than 1:6,400 on ELISA except for 2 samples, but weak or absent in sera with titers of 1:3,200. Agglutination was absent in sera of which the antibody titers were less than $1: 3,200$ on ELISA.

Conclusion We could rapidly detect serum IgM and IgG anti-GM1, GD1b, GQ1b and GM2 antibodies in patients with GBS by means of the latex agglutination assay when sera exhibited high titers of the respective antibodies on ELISA. The sensitivity of our agglutination assay was much lower than that of ELISA.

(Internal Medicine 42: 490-495, 2003)
\end{abstract}

Key words: anti-ganglioside antibody, latex agglutination assay, Guillain-Barré syndrome, enzyme-linked immunosorbent assay, anti-GM1 antibody, antiGQ1b antibody

\section{Introduction}

Serum anti-ganglioside antibodies have been assayed by thin-layer chromatography (TLC) or enzyme-linked immunosorbent assay (ELISA) in patients with Guillain-Barré syndrome (GBS), and its variant Miller Fisher syndrome (MFS) (1-12). As a result of this prevalence, it is known that some types of anti-ganglioside antibodies are specifically linked with the antecedent events or clinical features in GBS. Serum IgG anti-GM1 antibodies with or without anti-GD1b antibodies, which are often present after Campylobacter jejuni enteritis $(3,13-15)$, sometimes cause acute motor axonal (AMAN) or motor and sensory axonal neuropathy (AMSAN) $(16,17)$. IgM anti-GM2 antibodies occur in patients, frequently associated with facial palsy and sensory neuropathy, with an antecedent CMV infection $(9,18,19)$. IgG anti-GQ1b antibodies frequently occur in patients with acute ophthalmoplegia following GBS, MFS, or Bickerstaff's brainstem encephalitis $(5,20-23)$. In particular, around $90 \%$ of patients with MFS have these antibodies in the acute stage of the illness $(21,24)$.

Therefore, the detection of serum anti-ganglioside antibodies suggests the possibility that a patient has GBS, or one of its variants, including MFS or Bickerstaff's brainstem encephalitis. The assaying of anti-ganglioside antibodies seems to be very useful as a laboratory diagnostic test for the above diseases. Moreover, among these diseases, because early

From the Department of Neurology, Kitasato University School of Medicine, Sagamihara and *the Department of Rehabilitation, Kitasato University School of Allied Health Sciences, Sagamihara

Received for publication October 10, 2002; Accepted for publication January 6, 2003

Reprint requests should be addressed to Dr. Sachiko Irie, the Department of Neurology, Kitasato University East Hospital, 2-1-1 Asamizodai, Sagamihara $228-8520$ 
immunological treatment with plasmapheresis or intravenous gammaglobulins can shorten the term of illness and reduce sequelae $(25,26)$, early diagnosis by means of a rapid assay for anti-ganglioside antibodies would be useful for determining the treatment. Recently, Alaedini and Latov reported a rapid agglutination assay for anti-GM1 antibodies (27). We examined serum anti-ganglioside antibodies in patients with GBS using this latex agglutination assay, with some modifications, and compared the results with ELISA.

For editorial comment, see p 457.

\section{Materials and Methods}

\section{ELISA}

Sera from 147 patients with GBS were collected in our hospital and other institutions in Japan between April 1996 and March 2001. All patients were evaluated according to the established diagnostic criteria for GBS (28). Sera from 75 healthy adults were also collected as controls. The sera were all frozen at $-30^{\circ} \mathrm{C}$ until use. We examined serum IgM and IgG anti-GM1, GD1b, GQ1b, GD1a, GT1b, GM2 and GT1a antibodies by ELISA according to the previous method (29) with some modifications. Briefly, some of the wells of a polystyrene plate (Costar, Cambridge, MA) were coated with 200 pmol of each ganglioside (except GQ1b, Sigma Chemicals, St. Louis, MO; GQ1b, BioCarb, Lund, Sweden) in $20 \mu \mathrm{l}$ of methanol. The coated and uncoated wells were then saturated with $200 \mu \mathrm{l}$ of an ELISA solution comprising $1 \%$ bovine serum albumin (BSA) in PBS $(0.14 \mathrm{M} \mathrm{NaCl}, 0.01$ $\mathrm{M} \mathrm{NaH}_{2} \mathrm{PO}_{4}$, pH 7.4) for 2 hours. Then $100 \mu \mathrm{l}$ of serum diluted with the same solution was added. The plate was incubated overnight at $4^{\circ} \mathrm{C}$ and then washed. Peroxidaseconjugated goat anti-human IgG $(100 \mu \mathrm{l})$ or IgM antibodies (Cappel, West Chester, PA) diluted to $1: 1,000$ with the BSA/PBS solution were then added. After 1 hour incubation, the wells were washed, and $100 \mu$ of a developing solution composed of $0.04 \% o$-phenylenediamine, $0.024 \mathrm{M}$ sodium citrate, $0.05 \mathrm{M} \mathrm{Na}_{2} \mathrm{HPO}_{4}$, pH 5.0, and $0.003 \% \mathrm{H}_{2} \mathrm{O}_{2}$ was added. The reaction products were measured spectrophotometrically at $490 \mathrm{~nm}$ after 1 hour incubation. The optical density obtained after subtracting the uncoated background was regarded as the value for each anti-ganglioside antibody. The cutoff value for serum anti-ganglioside antibodies at 1:100 dilution was determined from the mean (M) and standard deviation (SD) of normal control values, i.e. M+5 SD, except for IgM anti-GM1 and GT1b antibodies, for which the cutoff value was $\mathrm{M}+3 \mathrm{SD}$, because the values for IgM anti-GM1 and GT1b antibodies were sometimes high in normal controls. Each antibody was considered positive when its value was above the cutoff value. The titers of antiganglioside antibodies were confirmed by means of serial 2fold dilution.

\section{Latex agglutination assay}

For 75 sera which exhibited various IgG anti-GM1, GD1b, or GQ1b antibody, or IgM anti-GM2 antibody titers on ELISA, we employed the rapid agglutination assay developed by Alaedini and Latov (27) with some modifications. Overall, a total of 104 samples from 75 patients were tested. A $1 \mathrm{mg} / \mathrm{ml}$ solution of GM1, GD1b, GQ1b or GM2 was prepared by combining $250 \mu \mathrm{g}$ of the ganglioside in $20 \mu \mathrm{l}$ of methanol with $105 \mu \mathrm{l}$ of $\mathrm{H}_{2} \mathrm{O}$ and $125 \mu \mathrm{l}$ of $100 \mathrm{mM}$ 2-(Nmorpholino)ethanesulfonic acid (MES) buffer (pH 6.1) in a $500 \mu \mathrm{l}$ conical tube. A volume of $250 \mu \mathrm{l}$ of a $2.5 \%$ suspension of $0.3 \mu \mathrm{m}$ blue polystyrene latex particles (Seradyn Particle Technology, Indianapolis, IN) was added to each ganglioside solution, followed by stirring for 4 hours at room temperature. Then the suspension was incubated for 48 hours at $4^{\circ} \mathrm{C}$. The particles were washed twice with a solution of $1 \%$ BSA in $25 \mathrm{mM}$ MES buffer ( $\mathrm{pH}$ 6.1), centrifuged at $9,800 \times g$, and then resuspended in the same solution. The beads coated passively with the ganglioside were incubated for 48 hours at $4^{\circ} \mathrm{C}$ before use. For the agglutination reaction, $4 \mu \mathrm{l}$ of serum and the same amount of gangliosidecoated latex beads were mixed on a 3-ring glass slide (CelLine, Newfield, NJ), followed by rocking for 30 to 40 seconds. Agglutination, characterized by clumps of beads, was confirmed under a microscope ( $\times 200$ magnification). When the reaction was indistinct, the beads and serum were incubated for a further 30 minutes at room temperature before a second observation. The serum which exhibited a high IgG anti-GM1 antibody titer of $1: 51,200$ was tested by means of serial 2-fold dilution.

\section{Results}

\section{ELISA}

Serum IgG or IgM antibodies to gangliosides were detected in $86(58.5 \%)$ of the 147 GBS patients and $4(5.3 \%)$ of the 75 controls, as demonstrated in Table 1. Among the 86 patients with anti-ganglioside antibodies, 84 (97.7\% of positive patients) had IgG or IgM anti-GM1, GD1b, GQ1b or GM2 antibodies. One patient had only IgG anti-GD1a antibodies and the other only IgG anti-GT1a antibodies. All patients with anti-GT1b antibodies had other kinds of antiganglioside antibodies. IgG anti-GM1, GD1b or GQ1b antibodies, or IgM anti-GM2 antibodies, as major antiganglioside antibodies, were detected in 75 patients, including 29 with 2 kinds of these antibodies (Table 2). The titers of these major anti-ganglioside antibodies were distributed between $1: 100$ and $1: 51,200$ (Fig. 1 and Table 2).

\section{Agglutination assay}

Agglutination was strong in the sera of which the IgM or IgG titers of anti-GM1, GD1b, GQ1b or GM2 antibodies were found to be $1: 6,400$ or more than $1: 6,400$ on previous ELISA except for 2 samples, but weak or absent in sera with titers of $1: 3,200$ (Figs. 2 and 3, and Table 2). Agglutination was absent in sera of which the anti-ganglioside 
IRIE et al

Table 1. Incidence of Anti-ganglioside Antibodies on ELISA

\begin{tabular}{|c|c|c|c|c|c|c|c|c|c|}
\hline \multicolumn{10}{|c|}{ a) IgG anti-ganglioside antibodies } \\
\hline & No. & GM1 & GD1b & GQ1b & GM2 & GD1a & GT1a & GT1b & Total \\
\hline GBS & 147 & $\begin{array}{c}29 \\
(19.7 \%)\end{array}$ & $\begin{array}{c}34 \\
(23.1 \%)\end{array}$ & $\begin{array}{c}23 \\
(15.6 \%)\end{array}$ & $\begin{array}{c}9 \\
(6.1 \%)\end{array}$ & $\begin{array}{c}13 \\
(8.8 \%)\end{array}$ & $\begin{array}{c}24 \\
(16.3 \%)\end{array}$ & $\begin{array}{c}8 \\
(5.4 \%)\end{array}$ & $\begin{array}{c}74 \\
(50.3 \%)\end{array}$ \\
\hline $\mathrm{NC}$ & 75 & $\begin{array}{c}0 \\
(0 \%)\end{array}$ & $\begin{array}{c}0 \\
(0 \%)\end{array}$ & $\begin{array}{c}0 \\
(0 \%)\end{array}$ & $\begin{array}{c}0 \\
(0 \%)\end{array}$ & $\begin{array}{c}0 \\
(0 \%)\end{array}$ & $\begin{array}{c}0 \\
(0 \%)\end{array}$ & $\begin{array}{c}0 \\
(0 \%)\end{array}$ & $\begin{array}{c}0 \\
(0 \%)\end{array}$ \\
\hline \multicolumn{10}{|c|}{ b) IgM anti-ganglioside antibodies } \\
\hline & No. & GM1 & GD1b & GQ1b & GM2 & GD1a & GT1a & GT1b & Total \\
\hline GBS & 147 & $\begin{array}{c}32 \\
(21.8 \%)\end{array}$ & $\begin{array}{c}26 \\
(17.7 \%)\end{array}$ & $\begin{array}{c}17 \\
(11.2 \%)\end{array}$ & $\begin{array}{c}18 \\
(12.2 \%)\end{array}$ & $\begin{array}{c}11 \\
(7.5 \%)\end{array}$ & $\begin{array}{c}12 \\
(8.2 \%)\end{array}$ & $\begin{array}{c}0 \\
(0 \%)\end{array}$ & $\begin{array}{c}63 \\
(42.9 \%)\end{array}$ \\
\hline $\mathrm{NC}$ & 75 & $\begin{array}{c}2 \\
(2.7 \%)\end{array}$ & $\begin{array}{c}0 \\
(0 \%)\end{array}$ & $\begin{array}{c}0 \\
(0 \%)\end{array}$ & $\begin{array}{c}1 \\
(1.3 \%)\end{array}$ & $\begin{array}{c}1 \\
(1.3 \%)\end{array}$ & $\begin{array}{c}0 \\
(0 \%)\end{array}$ & $\begin{array}{c}0 \\
(0 \%)\end{array}$ & $\begin{array}{c}4 \\
(5.3 \%)\end{array}$ \\
\hline \multicolumn{10}{|c|}{ c) IgG or IgM anti-ganglioside antibodies } \\
\hline & No. & GM1 & GD1b & GQ1b & GM2 & GD1a & GT1a & GT1b & Total \\
\hline GBS & 147 & $\begin{array}{c}41 \\
(27.9 \%)\end{array}$ & $\begin{array}{c}45 \\
(30.6 \%)\end{array}$ & $\begin{array}{c}25 \\
(17.0 \%)\end{array}$ & $\begin{array}{c}19 \\
(12.9 \%)\end{array}$ & $\begin{array}{c}17 \\
(11.2 \%)\end{array}$ & $\begin{array}{c}26 \\
(17.7 \%)\end{array}$ & $\begin{array}{c}8 \\
(5.4 \%)\end{array}$ & $\begin{array}{c}86 \\
(58.5 \%)\end{array}$ \\
\hline $\mathrm{NC}$ & 75 & $\begin{array}{c}2 \\
(2.7 \%)\end{array}$ & $\begin{array}{c}0 \\
(0 \%)\end{array}$ & $\begin{array}{c}0 \\
(0 \%)\end{array}$ & $\begin{array}{c}1 \\
(1.3 \%)\end{array}$ & $\begin{array}{c}1 \\
(1.3 \%)\end{array}$ & $\begin{array}{c}0 \\
(0 \%)\end{array}$ & $\begin{array}{c}0 \\
(0 \%)\end{array}$ & $\begin{array}{c}4 \\
(5.3 \%)\end{array}$ \\
\hline
\end{tabular}

GBS: Guillain-Barré syndrome, NC: normal controls.

Table 2. Comparison of the Positive Rates between ELISA and the Latex Agglutination Assay for Major Anti-ganglioside Antibodies in 147 Patients with GuillainBarré Syndrome

\begin{tabular}{ccc}
\hline ELISA & & Latex agglutination assay \\
\hline IgG anti-GM1 antibody & $29(19.7 \%)$ & $11(7.5 \%)$ \\
$\geqq 1: 6,400$ & 10 & 10 \\
$1: 3,200$ & 2 & 1 \\
$\leqq 1: 1,600$ & 17 & 0 \\
IgG anti-GD1b antibody & $34(23.1 \%)$ & $4(2.7 \%)$ \\
$\geqq 1: 6,400$ & 5 & 4 \\
$1: 3,200$ & 1 & 0 \\
$\leqq 1: 1,600$ & 28 & 0 \\
$\geqq 1: 6,400$ & $23(15.6 \%)$ & $5(3.4 \%)$ \\
$1: 3,200$ & 6 & 5 \\
$\leqq 1: 1,600$ & 1 & 0 \\
IgG anti-GQ1b antibody & 16 & 0 \\
$\geqq 1: 6,400$ & $18(12.2 \%)$ & $2(1.4 \%)$ \\
$\leqq 1: 1,600$ & 2 & 2 \\
IgM anti-GM2 antibody & 16 & 0 \\
Major anti-ganglioside antibodies & $75(51.0 \%)^{*}$ & $18(12.2 \%)^{* *}$ \\
\hline
\end{tabular}

*Including 29 patients with 2 kinds of major anti-ganglioside antibodies. **Including 4 patients with 2 kinds of major anti-ganglioside antibodies.

antibody titers were less than $1: 3,200$ on ELISA. With the serum of which the ELISA titer of IgG anti-GM1 antibodies was $1: 51,200$, the agglutination was greatly diminished in the serum diluted 32 times (Fig. 4).

Overall, agglutination was detected in $18(24.0 \%)$ of 75 GBS patients with IgG anti-GM1, GD1b or GQ1b, or IgM anti-GM2 antibodies on ELISA (Table 2). Despite the fact that the positive rate for the agglutination assay was $21.2 \%$ for all 104 samples, it was $91.3 \%$ for the 23 samples with high titers $(1: 6,400$ or more than $1: 6,400)$ of anti- ganglioside antibodies on ELISA.

\section{Discussion}

There have only been a few reports demonstrating the frequency of serum anti-ganglioside antibodies in GBS patients who had been tested by ELISA for more than 5 species of gangliosides, including at least anti-GM1, GD1b, GQ1b, GD1a and GM2 $(12,17,30)$. In the largest study, Miyazaki et al showed that $241(54.2 \%)$ of 445 GBS patients had at 


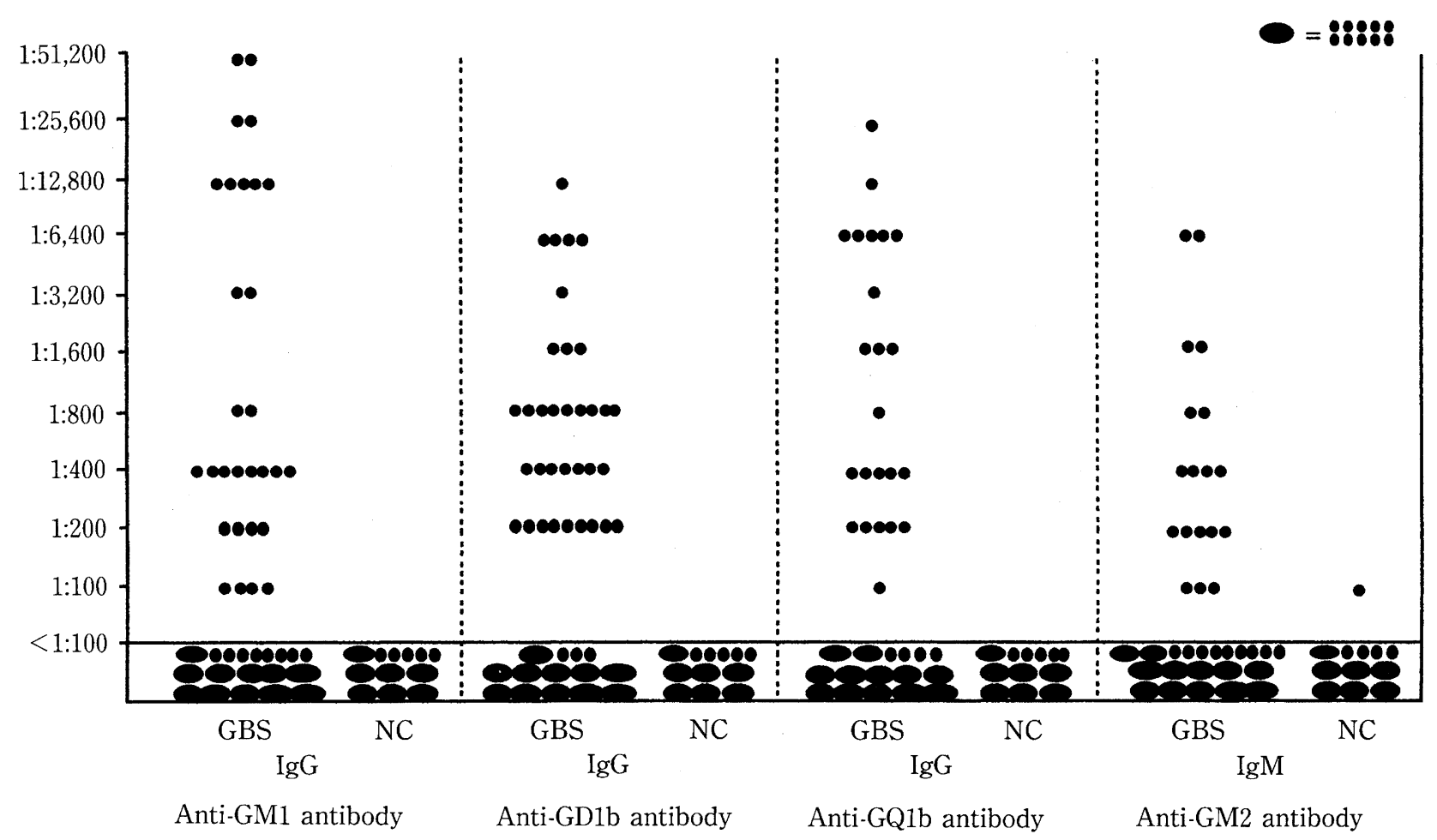

Figure 1. ELISA titers of major anti-ganglioside antibodies in 147 patients with Guillain-Barré syndrome and in 75 normal controls. GBS: Guillain-Barré syndrome, NC: normal controls.

GM1

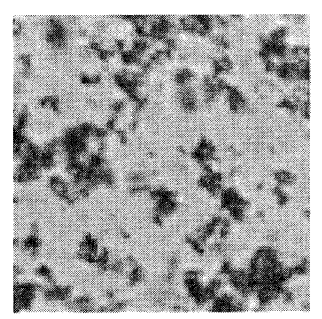

$1: 51,200$

( $\operatorname{Ig} G)$
GD1b

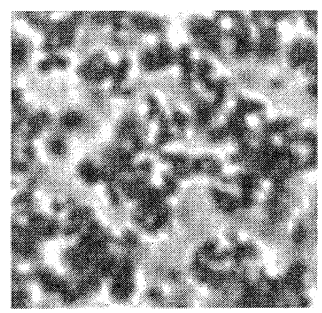

$1: 6,400$

( $\operatorname{IgG})$
GQ1b

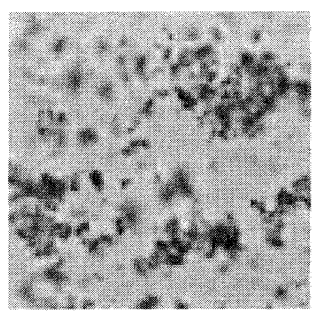

$1: 25,600$

( $\mathrm{IgG})$
GM2

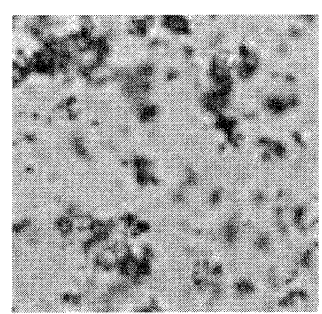

$1: 6,400$

$(\operatorname{Ig} \mathrm{M})$
GM1

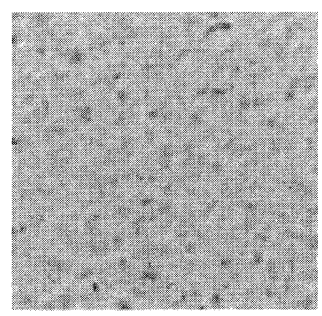

$<1: 100$

Figure 2. Latex agglutination and ELISA titers. ELISA titers are shown at the bottom. Anti-GM1, GD1b, GQ1b and GM2 anti-ganglioside antibodies were detected by means of the agglutination assay in samples exhibiting high titers of antibodies on ELISA.

least one of the anti-ganglioside antibodies (12). In the present study, anti-GM1, GD1b, GQ1b, GD1a, GT1b, GM2 and GT1a antibodies were seen in $58.5 \%$ of the 147 GBS patients. The levels of major serum anti-ganglioside antibodies in GBS patients were $27.9 \%$ of anti-GM1 antibodies (19.7\% of $\mathrm{IgG}), 30.6 \%$ of anti-GD1b antibodies ( $23.1 \%$ of $\mathrm{IgG})$, $17.0 \%$ of anti-GQ1b antibodies (15.6\% of IgG), and $12.9 \%$ of anti-GM2 antibodies (12.2\% of IgM). Overall, anti-GM1, GD1b, GQ1b or GM2 antibodies were seen in $57.1 \%$ of the GBS patients, accounting for $97.7 \%$ of all patients with antiganglioside antibodies. Anti-GD1a, GT1b and GT1a anti- bodies can rarely occur independently, as shown from our results. In addition, among the recent 35 patients with GBS for whom we measured anti-GalNAc-GD1a antibodies, all 6 patients associated with anti-GalNAc-GD1a antibodies also had antibodies to GM1, GQ1b or GM2. Serum antibodies to GM1b and LM1 are also rarely detected independently (10, 11). Therefore, it might be less common to detect antiganglioside antibodies that do not cross-react with GM1, GD1b, GQ1b or GM2.

Although examination of anti-ganglioside antibodies has been more routine for the diagnosis and more meaningful for 


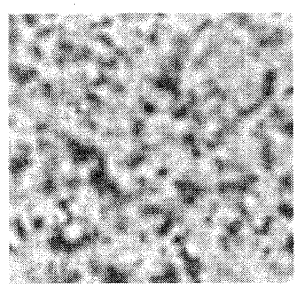

1:51,200

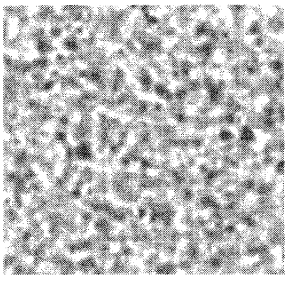

1:3,200

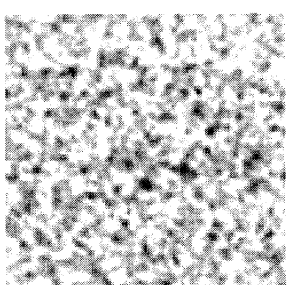

1:25,600

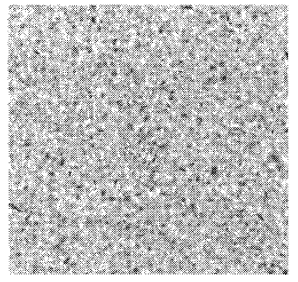

1:3,200

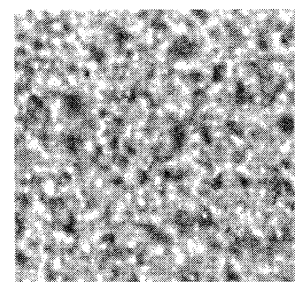

1:12,800

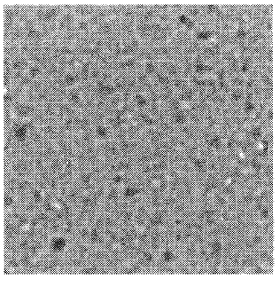

$1: 1,600$

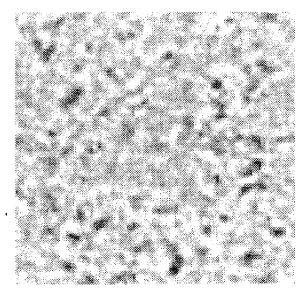

1:6,400

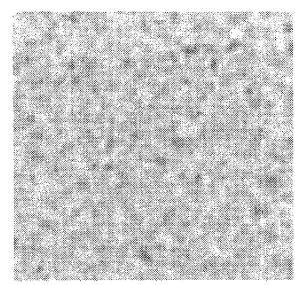

1:400

Figure 3. Latex agglutination with samples exhibiting various titers of IgG anti-GM1 antibodies on ELISA. Samples with titers of 1:6,400 or more than 1:6,400 on ELISA were positive, samples with titers of 1:3,200 were slightly positive or negative, and samples with titers of less than $1: 3,200$ were negative.

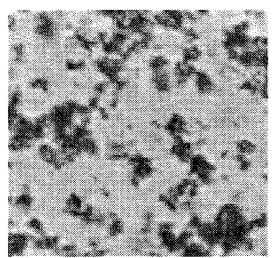

$\times 1$

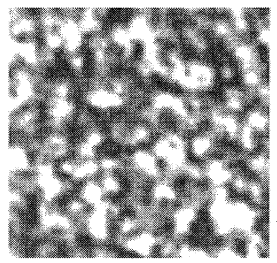

$\times 1 / 8$

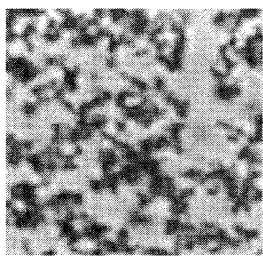

$\times 1 / 2$

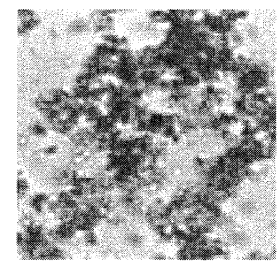

$\times 1 / 16$

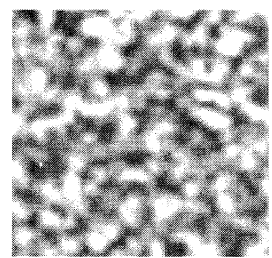

$\times 1 / 4$

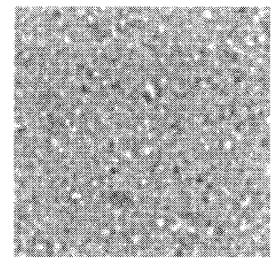

$\times 1 / 32$
Figure 4. Latex agglutination assay of the serum of which the ELISA titer of IgG anti-GM1 antibodies was 1:51,200 with serial 2-fold dilution. Agglutination was greatly diminished in the serum diluted 32 times.

investigation of the pathogenesis in patients with GBS and its variants, ELISA is bothersome due to the many processes including coating of wells with ganglioside, incubation of serum, usually overnight, reaction with enzyme-conjugated antibodies to human immunoglobulins, development with a substrate, and finally measurement of absorbance. TLC, which has also been a commonly used method for the detection of anti-ganglioside antibodies, requires more complicated processes and higher technical skill. The establishment of a more convenient and rapid method for anti-ganglioside antibodies is an obvious necessity, because the detection of these antibodies facilitates diagnosis and allows the early start of treatment in patients with GBS. In comparison with ELISA and TLC, the latex agglutination assay is very convenient, and only a few minutes are needed to visualize the reaction without any second antibodies or developing material when ganglioside-coated latex beads are prepared in advance.

In the present study, we were able to detect anti-GM1, GD1b, GQ1b and GM2 antibodies with this agglutination assay. However, we only observed a positive reaction in sera with titers of at least $1: 6,400$ of anti-ganglioside antibodies on ELISA. We could detect anti-GM1, GD1b, GQ1b and GM2 antibodies in only $24 \%$ of the positive patients as compared with ELISA. This means that the sensitivity of this agglutination assay is much lower than that of ELISA. Recently, Alaedini et al detected anti-ganglioside antibodies using crude bovine gangliosides by means of their latex agglutination assay in 21 of $40(53 \%)$ patients with GBS, including acute inflammatory demyelinating polyneuropathy, AMAN, AMSAN and MFS, but in $43 \%$ with their ELISA for anti-GM1, GM2, GD1a, GD1b, GT1b and GQ1b (31). Although in the total extract it is unknown with which ganglioside the sera react, the positive rate of antiganglioside antibodies in their agglutination assay was $123.3 \%$ as compared with their ELISA. They explain that this high rate is due to the presence of antibodies to minor ganglioside species in the total antigenic extract and that the agglutination assay measures a more physiological interaction than in the case of ELISA. Excluding MFS, Alaedini et al detected anti-ganglioside antibodies in 50\% of GBS pa- 


\section{Rapid Assay of Anti-ganglioside Antibody}

tients with their agglutination assay and only in 39\% of GBS patients with their ELISA; this frequency is much lower than those of a recent large study by Miyazaki et al (12) and in the present study. The sensitivity of their ELISA could be lower than our ELISA. Because serum antibodies only to minor gangliosides might rarely occur, as mentioned above, it is possible that Alaedini et al may have detected nearly all of the major anti-ganglioside antibodies with their agglutination assay. It is unknown why there is a large discrepancy between the results of Alaedini et al using the total ganglioside extract and ours using purified gangliosides. The total ganglioside extract could contain other glycolipids and unknown substances as impurities, and therefore agglutination could have been promoted by some impurities in their assay.

It is important to detect serum anti-ganglioside antibodies rapidly in patients with GBS and its variants for immediate treatment. We suggest that a latex agglutination assay is a very convenient and rapid method for examining serum antibodies to gangliosides. More modifications are needed to increase the sensitivity of our agglutination assay.

Acknowledgments: This study was supported in part by the Research Grant for the Neuroimmunological Diseases from the Ministry of Health and Welfare, Japan. We thank Dr. Armin Alaedini, Cornell University, New York, USA, for the useful comments regarding the latex agglutination assay.

\section{References}

1) Ilyas AA, Willison $\mathrm{HJ}$, Quarles $\mathrm{RH}$, et al. Serum antibodies to gangliosides in Guillain-Barré syndrome. Ann Neurol 23: 440-447, 1988.

2) Nobile-Orazio E, Carpo M, Legname G, Meucci N, Sonnino $S$, Scarlato G. Anti-GM1 IgM antibodies in motor neuron disease and neuropathy. Neurology 40: 1747-1750, 1990.

3) Yuki N, Yoshino H, Sato S, Miyatake T. Acute axonal polyneuropathy associated with anti-GM1 antibodies following Campylobacter enteritis. Neurology 40: 1900-1902, 1990.

4) Ilyas AA, Mithen FA, Dalakas MC, Chen ZW, Cook SD. Antibodies to acidic glycolipids in Guillain-Barré syndrome and chronic inflammatory demyelinating polyneuropathy. J Neurol Sci 107: 111-121, 1992.

5) Chiba A, Kusunoki S, Shimizu T, Kanazawa I. Serum IgG antibody to ganglioside GQ1b is a possible marker of Miller Fisher syndrome. Ann Neurol 31: 677-679, 1992.

6) Yuki N, Yamada M, Sato S, et al. Association of IgG anti-GD1a antibody with severe Guillain-Barré syndrome. Muscle Nerve 16: 642647, 1993.

7) Kusunoki S, Chiba A, Kon K, et al. N-Acetylgalactosaminyl GD1a is a target molecule for serum antibody in Guillain-Barré syndrome. Ann Neurol 35: 570-576, 1994.

8) Mizoguchi K, Hase A, Obi T, et al. Two species of anti-ganglioside antibodies in a patient with a pharyngeal-cervical-brachial variant of Guillain-Barré syndrome. J Neurol Neurosurg Psychiatry 57: 11211123, 1994.

9) Irie S, Saito T, Nakamura K, et al. Association of anti-GM2 antibodies in Guillain-Barré syndrome with acute cytomegalovirus infection. J Neuroimmunol 68: 19-26, 1996.

10) Kusunoki S, Iwamori M, Chiba A, Hitoshi S, Arita M, Kanazawa I. GM1b is a new member of antigen for serum antibody in GuillainBarré syndrome. Neurology 47: 237-242, 1996.
11) Yako K, Kusunoki S, Kanazawa I. Serum antibody against a peripheral nerve myelin ganglioside, LM1, in Guillain-Barré syndrome. J Neurol Sci 168: 85-89, 1999.

12) Miyazaki T, Kusunoki S, Kaida K, Shiina M, Kanazawa I. GuillainBarré syndrome associated with IgG monospecific to ganglioside GD1b. Neurology 56: 1227-1229, 2001.

13) Walsh FS, Cronin M, Koblar S, et al. Association between glycoconjugate antibodies and Campylobacter infection in patients with Guillain-Barré syndrome. J Neuroimmunol 34: 43-51, 1991.

14) Gregson NA, Koblar S, Hughes RAC. Antibodies to gangliosides in Guillain-Barré syndrome: specificity and relationship to clinical features. Q J Med 86: 111-117, 1993.

15) Vriesendorp FJ, Mishu B, Blaser MJ, Koski CL. Serum antibodies to GM1, GD1b, peripheral nerve myelin, and Campylobacter jejuni in patients with Guillain-Barré syndrome and controls: correlation and prognosis. Ann Neurol 34: 130-135, 1993.

16) Yuki N, Kuwabara S, Koga M, Hirata K. Acute motor axonal neuropathy and acute motor-sensory axonal neuropathy share a common immunological profile. J Neurol Sci 168: 121-126, 1999.

17) Ogawara K, Kuwabara S, Mori M, Hattori T, Koga M, Yuki N. Axonal Guillain-Barré syndrome: relation to anti-ganglioside antibodies and Campylobacter jejuni infection in Japan. Ann Neurol 48: 624-631, 2000.

18) Jacobs BC, van Doorn PA, Groeneveld JHM, Tio-Gillen AP, van der Meché FGA. Cytomegalovirus infections and anti-GM2 antibodies in Guillain-Barré syndrome. J Neurol Neurosurg Psychiatry 62: 641-643, 1997.

19) Yuki N, Tagawa Y. Acute cytomegalovirus infection and IgM antiGM2 antibody. J Neurol Sci 154: 14-17, 1998.

20) Yuki N, Sato $S$, Tsuji $S$, Ohsawa $T$, Miyatake T. Frequent presence of anti-GQ1b antibody in Fisher's syndrome. Neurology 43: 414-417, 1993.

21) Chiba A, Kusunoki S, Obata H, Machinami R, Kanazawa I. Serum anti-GQ1b IgG antibody is associated with ophthalmoplegia in Miller Fisher syndrome and Guillain-Barré syndrome: Clinical and immunohistochemical studies. Neurology 43: 1911-1917, 1993.

22) Willison HJ, Veitch J, Paterson G, Kennedy PGE. Miller Fisher syndrome is associated with serum antibodies to GQ1b ganglioside. J Neurol Neurosurg Psychiatry 56: 204-206, 1993.

23) Yuki N, Sato S, Tsuji S, Hozumi I, Miyatake T. An immunologic abnormality common to Bickerstaff's brain stem encephalitis and Fisher's syndrome. J Neurol Sci 118: 83-87, 1993.

24) Mori M, Kuwabara S, Fukutake T, Yuki N, Hattori T. Clinical features and prognosis of Miller Fisher syndrome. Neurology 56: 1104-1106, 2001.

25) Hahn AF. Guillain-Barré syndrome. Lancet 352: 635-641, 1998.

26) Asbury AK. New concepts of Guillain-Barré syndrome. J Child Neurol 15: 183-191, 2000.

27) Alaedini A, Latov N. Detection of anti-GM1 ganglioside antibodies in patients with neuropathy by a novel latex agglutination assay. J Immunoassay 21: 377-386, 2000.

28) Asbury AK, Cornblath DR. Assessment of current diagnostic criteria for Guillain-Barré syndrome. Ann Neurol 27 Suppl: S21-S24, 1990.

29) Sadiq SA, Thomas FP, Kilidireas K, et al. The spectrum of neurologic disease associated with anti-GM1 antibodies. Neurology 40: 10671072, 1990.

30) Carpo M, Pedotti R, Allaria S, et al. Clinical presentation and outcome of Guillain-Barré and related syndromes in relation to anti-ganglioside antibodies. J Neurol Sci 168: 78-84, 1999.

31) Alaedini A, Briani C, Wirguin I, Siciliano G, D'Avino C, Latov N. Detection of anti-ganglioside antibodies in Guillain-Barré syndrome and its variants by the agglutination assay. J Neurol Sci 196: 41-44, 2002. 